The Mechanization of the Mind

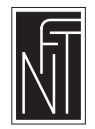




\title{
$\begin{array}{lllllllllllllllll} & \text { N E } & \text { W } & \text { F } & \text { R } & \text { E } & \text { N } & \text { G } & \text { H } & \text { T } & \text { H } & \text { O } & \text { U } & \text { G } & \text { H } & \text { T }\end{array}$
}

\author{
Series Editors \\ Thomas Pavel and Mark Lilla
}

Titles in the Series

Jacques Bouveresse, Wittgenstein Reads Freud: The Myth of the Unconscious Jean-Pierre Dupuy, The Mechanization of the Mind: On the Origins of Cognitive Science

Marcel Gauchet, The Disenchantment of the World: A Political History of Religion Marcel Gauchet and Gladys Swain, Madness and Democracy: The Modern Psychiatric Universe Blandine Kriegel, The State and the Rule of Law Mark Lilla, ed., New French Thought: Political Philosophy Gilles Lipovetsky, The Empire of Fashion: Dressing Modern Democracy Pierre Manent, The City of Man Pierre Manent, An Intellectual History of Liberalism

Alain Renaut, The Era of the Individual: A Contribution to a History of Subjectivity Pierre Rosanvallon, The New Social Question: Rethinking the Welfare State Jean-Marie Schaeffer, Art of the Modern Age: Philosophy of Art from Kant to Heidegger 
Jean-Pierre Dupuy

\section{The Mechanization of the Mind}

ON THE ORIGINS OF GOGNITIVE SGIENCE

Translated by M. B. DeBevoise

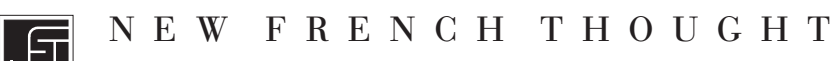


English translation copyright $\odot 2000$ by Princeton University Press

Published by Princeton University Press, $4 \mathrm{I}$ William Street,

Princeton, New Jersey 08540

In the United Kingdom: Princeton University Press, 3 Market Place,

Woodstock, Oxfordshire ox20 IsY

Translated from Jean-Pierre Dupuy, Aux origines des sciences cognitives.

Copyright () I994. La Découverte, Paris.

All Rights Reserved

Library of Congress Cataloging-in-Publication Data

Dupuy, Jean-Pierre. 1941-

[Aux origines des sciences cognitives. English]

The mechanization of the mind : on the origins of cognitive science / Jean-Pierre Dupuy ; translated by M.B. DeBevoise.

p. cm. - (New French thought)

Includes bibliographical references and index.

ISBN 0-69I-02574-6 (alk. paper)

1. Cognitive science-History. I. Title. II. Series.

BF311.D84513 2000

153—dc21 00-032675

Publication of this book has been aided by the French Ministry of Culture

This book has been composed in Adobe Bauer Bodoni

The paper used in this publication meets the minimum requirements of ANsI/NIso Z39.48-I992 (R 1997) (Permanence of Paper)

www.pup.princeton.edu

Printed in the United States of America

$\begin{array}{llllllllll}\text { IO } & 9 & 8 & 7 & 6 & 5 & 4 & 3 & 2 & \text { I }\end{array}$ 
In Memory of Jean Ullmo

For Heinz von Foerster 
